\title{
Valuation of Private Universities Library Resources: What to Look Out for While Valuing Same and Things needed to be considered before Arriving at Fair Opinion of Value
}

\author{
Ifediora,Christian Osita ${ }^{1}$, Keke, Onyinye Vivian ${ }^{2}$ \\ National Diploma/B Sc. Estate Management, M Sc. Estate Management (Project Management Option), \\ Paul University Awka, Anambra State.
}

B Sc., M Sc. Estate Management, Lecturer, Department of Estate Management, NnamdiAzikiwe University Awka, Anambra State

\begin{abstract}
The work essentially covers the aspect of valuation which is seen as forgotten by Valuers or actually that which rarely comes by. Even when remembered or comes by, how to identify what to place value on becomes a pressing issue/challenge and mode/process of valuation becomes tasking. Also when what to value has been identified, how to carry out the valuation becomes another challenge. This work however identified those things to look out for; in addition it suggested how to carry out valuation of such resources. It concluded by urging practitioners to do more study on how to carryout valuation of library resources, this will help go a long way in valuation profession as there has not been an established method for valuing such resources.
\end{abstract}

Keywords: Valuation, Library, Resources, Estate Surveyors, Valuers, Private Universities.

\section{Introduction}

Many a times or in fact in most literatures, emphasis on valuation of libraries has been on the physical structures especially building and few majors components, while little or no attention has been paid on valuation of all library resources.

Valuation of library resources is rare and has been scare in the literature possibly because Valuers may not have been able to identify what to value. One may also be right if he opines that such valuation are rarely comes by. But what happens if an Estate Surveyor and Valuers is employed by the works department of any tertiary institution to serve as an internal Valuer and subsequently required to carry out valuation of Library resources in order to update the school management on the value of resources found in the library? What will he have to look out for? What and what is he expected to value? When he has identified what to value, how does he go about the valuation?

It is true that such valuations do rarely come by, but Valuers must first familiarize himself of the resources available in the library. One should know that valuing University libraries is beyond the physical furnishing, file cabinets, reading desks, etc. that are physically present in the library. Valuation of library resources should be far more than the valuing the tangible aspects of the resources available. There are so many intangible resources which may be seen aspects of the library which have add value to the institutions reputation and are not considered by the valuers while they carrying out the valuation of physical infrastructure of library using depreciated cost methods. Valuing other resources which some can be seen as the intangible is also very important because web ranking of most universities by webometrics are commonly based on web contents/presence, and many institution of higher learning have internal web/websites, access to other data bases were people can access the library resources, for instance the ranking of universities which ranked some universities above each other has in greater way added to the goodwill of Universities and Valuers also value goodwill. The emphasis here is not based on which universities is ranked first or last but facts remains that their resources which are available at libraries and according to the author are seen as intangible, Valuers most times do not consider them while valuing libraries.

One cannot deny the fact that libraries plays an important in real estate practices, in educational institution, one can equally confirm that even departments of Estate Management in several private and public universities have libraries even if not big, may have sizable libraries where they consult literatures whether in print or in soft or copies.

In most of all libraries as we may see in this work have sections which acquisition is part of, most libraries way of acquisition features; loan, grant, donations etc., all these terms are what Valuers are synonymous with in real estate management practices, hence we talk about rights, properties, chattels and goods.

It based on this premise that the author want to intimate readers and practitioners alike on what and what to look out for while valuing libraries to ensure that all interest are better represented the way it should before arriving at the final opinion of value of any institutions library.

\section{Aim and Objectives}

The study aims primarily at intimating the Valuers on the aspect of the practices which are either forgotten or may 


\section{International Journal of Science and Research (IJSR) \\ ISSN (Online): 2319-7064 \\ Index Copernicus Value (2013): 6.14 | Impact Factor (2014): 5.611}

have not arrived at away of valuing such important aspect of the practice, this its aims at achieving by identifying those resources that forms formidable part of the library and possibly suggest simply ways of arriving at the value of such resources whether in the library.

\section{Library defined: sections/departments in the library}

Library is derived from the Latin word "liber" which meansA BOOK. Earlier a library was "a place where books were written or kept". This term was frequently used as a "collection of books" and a librarian as a keeper or guard of books. This word has taken centuries to become central point of all social actions and has got recognition as a social institution. In my humble opinion, the definition of library is as today far beyond a place where books were written or kept as such definition does not take into consideration the e-library and other intangible aspect of the library into consideration. So any definition which do emphasize in details or parts some intangibles aspect which forms formidable part of learning is notcomplete.

Types of Libraries Broadly there are four types of libraries:

1. Public Library

2. Academic Library: It can be categorized in to three types:

a) School Library

b) College Library

c) University Library

3. Special Library; and

4. National Library.

For sake focus/emphasis we shall concentrate on the second type of library which is academic library and option $\mathrm{C}$ which is the university library.

An Academic Library has been defined as: "a library which is associated or attached with any educational institution to support its educational programmes". Academic library is an integral part of formal education system which provides time bound education from primary school level to university level. An academic library works as a base for teaching, learning, research etc. We can categorize academic libraries in to following three categories-

1. School Library

2. College Library

3. University Library.

\section{Classification of Library Resources}

Although libraries are normally associated with books, they have numerous other research resources, many of which are beyond the scope of what is easily accessible at home or on the Internet. Moreover, while libraries have a plethora of both physical and digital resources, some of their most valuable assets are their human resources. Librarians are knowledgeable about what information is accessible from each resource and can make your research efforts easier and more efficient.

\section{Physical Resources}

Libraries house a number of resources that you can locate, handle, and use immediately. These physical resources include periodicals, magazines, newspapers, maps, and manuscripts, though some may be used only at the library. In addition, many libraries provide media resources such as films, prints, CDs, cassettes, and videos that you can access during your visit. Of course, libraries also have books on a variety of subjects and often have book-sharing arrangements with other libraries, too.

\section{Digital Resources}

The advent of digital resources has greatly expanded the walls of libraries. Now, libraries have resources such as ebooks and online databases which are not limited to physical locations within the library.

Databases, in particular, are useful for researchers because they allow you to search for information by topic, category, author, date or other useful traits. However, many of the best databases are subscription based, so unless you work for a company that has a subscription or attend a university with one, the only practical (and affordable) place to get access is in the library.

Databases may specialize in a certain field such as medicine, business, or engineering. These databases provide access to not only historical information, but also information that is not easily found through search engines like Google. The indepth and historical information makes these databases one of the most valuable resources in the library.

\section{Human Resources}

Because libraries can house and/or access so much information, you may not discover what you need until you have spent a lot of time exploring what is available. Enlisting the help of a librarian can often save you time because librarians are trained to evaluate all of their libraries' resources, including the best ways for you to access them and whether they are the appropriate given your specific needs or interests. Librarians can also help you quickly learn to use technology or software, such as microfiche readers or database search programs, which you may need to complete your research.

\section{Sections/Departments in A Library and Suggested Methods of Valuing Resources Therein:}

Acquisitions: The division is responsible for the acquisition of library materials in the form of books, serials (printed and electronic), non-book materials (audio/ video tapes, microforms, CD-ROM etc.) and newspapers. Acquisition is done through purchase, subscription, and gift and exchange arrangements. Purchases and subscriptions are mainly through local agents or directly from publishers. The division is also responsible for maintaining the fiscal records of library funds for the purchase of materials. Some of items found may include: binding equipment, blocking machines, photocopiers.

Bindery: In most case the bindery unit of a library it set up to eliminate the inconvenience encountered with local Binders and to carter for the needs of the Library- that is mending torn and/ or worn-out books. 


\section{International Journal of Science and Research (IJSR) \\ ISSN (Online): 2319-7064}

Index Copernicus Value (2013): 6.14 | Impact Factor (2014): 5.611

Circulations: Circulation Services assists library patrons with the locations and circulations of library materials. Functions include check-outs and check-ins of materials, collection of fines and other charges, re-shelving of library materials, charging and discharging of library materials, registration of users, maintaining order in shelving areas. Circulation services also assist patrons with general questions about the University Library.

Cataloguing and Classification: This section involves the cataloguing and classification of incoming materials: the work process includes checking, identifying and verifying bibliographic details, content analysis, assignment of subject headings and call number, organization of bibliographic details, content analysis, assignment of subject headings and call number, organization of bibliographic details in a bibliographic record according to information categories, preparing the library materials for placing on the shelf: affixing spine label displaying call number and location label.

Reference: The Reference Section assists library clients, also known as patrons to locate items within the library and find information for specific purposes. It answers question by performing a quick internet search or performing a search on the library's computer system. Depending on the complexity of the question, the librarian may need to conduct additional research and get back to the patron with the correct answer. The Reference Librarian may also provide training for patrons or other library workers on using library equipment and library procedures. Reference section also helps in updating the library catalogue, since they deal with daily request from users.

Serials: The Serials Section manages the journals, newspapers, magazines and other periodicals that support curricular needs and compliment the general monograph and reference collections. The Serials Librarian is responsible for reporting and contributing to the decision and policies concerning the serials collections.

Valuing resources in this department must include proper identification of the resources available. What it cost/takes to procure these journals, newspapers, magazines and other periodicals should be of utmost concern to the Valuer.

Reprographic: This Section runs the duplication of all materials in the University Library. Resources found in this department include photocopying machines, scanners, computers etc. Since most of the resources here are electrical appliances. For a Valuer who is seeking for a way to value such he should be very careful in arriving at the final opinion of the value, he should do a thorough inspection, should also seek professional advice from experts in electrical appliances.

One will agree with me based on the above that libraries is broad if one decides to take it department by department, but for sake of concentration we shall consider the intangible aspect of the library which is mostly or greatly found under e-library section of the library.

E-Library: The E-library is the section of the library in which collections are stored in electronic media formats (as opposed to print, or other media) and accessible through computers. The components of the e-library may include: infrastructure: building housing the e-library itself, wooden cabinets/tables, desks, digital collections, system function, telecommunication facility and Human Resources. The electronic contents may be stored locally or accessed remotely. It coordinates the functionality of systems and library network. It houses CD-ROMs which are arranged into their component disciplines, downloads and prepares journals for binding, managing the e-books and e-journals of the library, working on developing Institutional Digitized Repository for the University and generating a comprehensive list of the books in the library. Majority of the resources found at the E-library is found in the intangible form.

\section{Intangible Aspects of Library Resources}

These are resources which can be found in soft copy and can simply be found at the e-library. This does not mean that they cannot be found in other sections of the library as support tools. The intangible resources can also be found on the other sections of the library. These resources includes the: e-books, online journals, books stored in CD's, DVD's, audio tapes, recorders, laptops, mini laptops, external disks, desktop computers, diskettes, etc. others may also include the Library websites, internal web design for internal access to certain information and documents, internal servers etc.

It should be noted that this particular literature is not looking at the physical state of the theses resources rather on the contents and the volume of informations available on such devices. While we appreciate the fact that most intangible resources cannot function properly without the tangible aspect, on cannot also denied that fact that these tangible resource are to library users of little or no value if the needed information by the Librarians are not contained or cannot be sourced in such resources.

\section{Theoretical Perspective to valuations of the intangible aspects of the library resources:}

The valuation should essentially start by identifying the tangible resources that contained the useful information/resources needed by the clients. These items are mostly found at the e-library and they includes: infrastructure: building housing the e-library itself, wooden cabinets/tables, desks, digital collections, system function, telecommunication facility and Human Resources, IT infrastructure: servers, wireless pots and terminals, furniture, equipment and space. They can also be in form of:

- Diskettes (though not in use these day).

- Audio/video tapes.

- CD's and DVD's.

- Laptops, mini laptops and diskettes.

- Libraries websites and internal webs.

While trying to carryout valuations of resources on this department one should consider the following:

What it cost to develop data base of the digital material that is open to all users over the campus-wide LAN.

What it take to effectively install high bandwidth internet connectivity.

How digital resources were selectively acquired.

How electronic journals were procured.

\section{Volume 4 Issue 11, November 2015}




\section{International Journal of Science and Research (IJSR) \\ ISSN (Online): 2319-7064 \\ Index Copernicus Value (2013): 6.14 | Impact Factor (2014): 5.611}

The issue of license of data bases.

How the digital content available within the university is developed.

\section{The CD'S}

Using the CD as case study, one should look at the volume and content of the material stored in such CD. It is very essential because with one (1) one can even produce or burn billions of the all that is contained in several other empty CD's, in the same vein billions of text books or journal, i.e. whatever is contained in such CD can be reproduced and be made available to people that needs such resources. We cannot also not deny the fact that the content can be uploaded to the net which anyone across the globe can download and make use of as he/she deems fit.

Also the same resources can be made available internally by pasting the content on the internal web and with the aid of networking of all systems, such resources can be made available to library users.

The value to the placed on the resources should such equal to the value obtainable when it is in hard copy or better still, the approach should be.

1) Open the $C D$ and determine the number of the pages of the resources.

2) Determine how much it can cost to reproduce such book as if it were in hard copy from a reputable publisher or if one need to get it done internally, then how much does the reprographic section or the e-librarian collects in printing a page which is the multiplied by the number $\mathrm{pf}$ paged of the resources contained in the $\mathrm{CD}$ in question.

3 ) If the latter option is chosen then, the cost of labour of binding it by the reprographer is considered. Determining the cost of labour should be based on the reprographers salary per month, and dividing by no of the hours/minutes it takes in producing or binding a copy

4) If no 3 above is the case, then the value of intangible resources is determined in relation to the cost it takes a reprographer to produce it.

5) If the resources content in question is taken to a printer/publishers outside the library, other issue like copy wright comes into play.

\section{Laptops and Desktop Computers:}

Emphasis should be on:

- The window version of such system and with reference to the similar windows available in the market e.g. windows $\mathrm{Xp}$, windows 7,8 etc.

- The installed memory, whether in gigs, megabytes and terabytes.

- The type of processor in caseof laptops whether Intel or AMD processors etc.

- Is the CD ROM/player working, can it read or writesplate?

- How long can the battery of laptops last when there are no power sources?

\section{Furnitures}

What is the type of furniture found in the e-library, wooden, metal or rubber? If wooden what type of wood? What about the age of the furniture? What of book shelf, what material is it made of?

\section{Electronics: Televisions, Fans, Air Conditioners}

The above listed must be carefully identified. Are they working properly?

\section{Books And Book Materials}

One should be able to know whether the book is from Nigerian Arthur and published locally, if locally then the age of the book i.e. when published should be known as this will help in assigning a value to it.He should also check if the books are foreign, if foreign then the cost of shipment must be taken into considerations in addition to the cost of the book taken into consideration the exchange rate. If the books are old, then adjustment must be made in terms of the age of the book in question.

\section{IT Infrastructure/Telecommunication Facility}

Proper identification of what constitutes IT infrastructure/telecommunication facilities is very essential here. What type of internal server available? What is the cost of installations? What is the server capacity? What makes up the major components of the internal server and which company manufactured those components? When was it installed and at what cost? What is the current cost of installing same? What about the LAN cables, are they working?

\section{Summary and Conclusion}

Resources available at the library are such that their importance to Valuer cannot be easily quantified. Those resources identified forms part of the valuation exercise of which a Valuer must pay a careful attention to before arriving at any opinion of value.

To this end, it's expected that Valuers should as matter professionalism get acquainted on what constitutes this all important aspect of the library. One should identify these resources and follow the way suggested above in arriving at the final opinion value for such resources. Practitioners should to do more by devoting time for researches/studies on how to carryout valuation of library resources, this will help go a long way in valuation profession as there has not been an established method for valuing most resources found in the library.

\section{References}

[1] Boundless."Types of Material in a Library." Boundless Communications. Boundless, 03 Jul. 2014. Retrieved 26 May. 2015 from https: // www. boundless.com /communications / textbooks / boundlesscommunications-textbook/topic-research-gatheringmaterials-and-evidence-8/library-research-42/types-ofmaterial-in-a-library-181-4162/

[2] Gupta Jyotsna: Types of libraries a lecture delivered at the Directorate of Distance Education Kurukshetra University, Kurukshetra. Available on http://www.foxitsoftware.com 
[3] http://edoc.huberlin.de/oa/articles/relz1hpFVJJZw/PDF/29n124GXni qTA.pdf

[4] http://edoc.huberlin.de/oa/articles/relz1hpFVJJZw/PDF/29n124GXni qTA.pdf

[5] http://infocuib.laborales.unam.mx/ ec08s02c/archivos/d ata/1/109.pdf

[6] http://nces.ed.gov/pubs2004/2004317.PDF

[7] http://www.ala.org/acrl/sites/ala.org.acrl/files/content/is sues/value/val_report.pdf

[8] http://www.clir.org/pubs/reports/pub129/pub129.pdf

[9] http://www.hibbing.mn.us/index.asp?SEC=88AFD0DD -E9FF-4E15-9E7A-EE91C597197D\&Type=B_LIST

[10] http://www.nlj.gov.jm/?q=library-jamaica-departments

[11] http://www.philosophyofinformation.net/publications/p df/isaspi.pdf

[12] http://www.unige.ch/biblio/ses/IFLA/rol_lib_030526.pd $\mathrm{f}$

[13] http://www.webpages.uidaho.edu/ mbolin/ugah1.htm

[14] https://ico.org.uk/media/fororganisations/documents/1217/definition-documenteducation-library-..

[15] https://library.nd.edu/about/departments/

[16] Michael Seadle\&ElkeGreifeneder (2007) Defining a digital library. www.emeraldinsight.com/07378831.htm

[17] www.pauluniversity.edu.ng. 